\title{
Tissue mineral nutrient content in turions of aquatic plants: does it represent a storage function?
}

\author{
Lubomír Adamec ${ }^{1}$ \\ Institute of Botany of the Academy of Sciences of the Czech Republic, Section of Plant Ecology, Třeboň, \\ Czech Republic
}

With 2 tables

\begin{abstract}
Turions are frost resistant, vegetative dormant organs produced by aquatic plants. Tissue N, P, K, Ca, and $\mathrm{Mg}$ content was estimated in turions of 5 rooting, non-carnivorous plant species of the genera Caldesia, Hydrocharis, and Potamogeton and in 7 rootless carnivorous plant species of the genera Aldrovanda and Utricularia, and compared with concentrations of these nutrients in ambient waters either in the field or in culture. Mean turion content of $\mathrm{N}$ in all species was $1.87 \% \mathrm{DW}, \mathrm{P} 0.26 \%, \mathrm{~K} 0.65 \%, \mathrm{Ca} 0.15 \%$, and of $\mathrm{Mg} 0.19 \% \mathrm{DW}$. Of all nutrients, only turion $\mathrm{K}$ content differed significantly between carnivorous and non-carnivorous species $(0.48 \pm 0.03$ vs. $1.04 \pm 0.10 \% \mathrm{DW})$. For all plant species and sites $(\mathrm{n}=18)$, turion nutrient content did not depend on nutrient concentrations in the ambient water at the time of turion initiation. Results of a literature survey conducted for the 12 plant species revealed that mean turion nutrient content was moderately $(\mathrm{N}, \mathrm{P})$ or markedly $(\mathrm{K}, \mathrm{Ca}, \mathrm{Mg}) \mathrm{lower}$ than shoot or leaf nutrient content for the same 12 species. In conclusion, turions of aquatic plants also represent storage organs for mineral nutrients $(\mathrm{N}, \mathrm{P})$ though their storage function is presumably less distinct than in the case of carbohydrates.
\end{abstract}

Key words: Carnivorous and non-carnivorous plants, turion $\mathrm{N}, \mathrm{P}, \mathrm{K}, \mathrm{Ca}$ and $\mathrm{Mg}$ content, water chemistry, storage organs, winter apices.

\section{Introduction}

Turions are vegetative dormant organs produced by perennial aquatic plants as a response to unfavourable ecological conditions (Sculthorpe 1967, Bartley $\&$ Spence 1987). Modified shoot apices, turions, are spherical (Utricularia), rhomboid (Aldrovanda) or torpedo-shaped (Potamogeton spp., Caldesia) tough and sturdy organs, formed at the end of the growing season by extreme condensation of short modified leaves in the shoot apex. Turions are frost resistant and protect fragile plant shoots from freezing and decaying (Winston \& Gorham 1979, Adamec 1999). They are storage organs and in autumn, they accumulate starch (9-70\% dry weight, DW) and free sugars (in total 7-14\% DW, Winston \& Gorham 1979, Kunii 1989, Ley et al. 1997, Adamec 1999, 2003a,b, Weber \& Noodén 2005). In Hydrocharis morsus-ranae turions, a great deal of the total organic $\mathrm{N}$ was found in the form of arginine (Villanueva et al. 1985). Turions of all aquatic plant species usually overwinter and break their innate dormancy at the bottom of an aquatic habitat in darkness, under hypoxic or anoxic conditions, usually lightly covered by organic sediments. However, concerning the overwintering, two distinct ecological strategies may be distinguished (Bartley \& Spence 1987, Ad-

\footnotetext{
Author's address:

${ }^{1}$ Institute of Botany of the Academy of Sciences of the Czech Republic, Section of Plant Ecology, Dukelská 135 , CZ-379 82 Třeboň, Czech Republic;

e-mail:lubo.adamec@seznam.cz
} 
amec 2008a). Turions of free-floating (non-rooted in the sediment) aquatic genera (e.g., Hydrocharis, Utricularia, Aldrovanda, Spirodela) ripen at the water surface, overwinter at the bottom, but usually germinate (sprout) at the water surface in warmer water, while those of aquatic rooted genera (e.g., Potamogeton, Caldesia, Myriophyllum) both ripen, germinate, and root at the bottom in colder water and shade (Sculthorpe 1967, Adamec 1999, 2008a). Moreover, turions of free-floating aquatic species differ in the mechanism of autumnal sinking and spring floating (Newton et al. 1978, Adamec 1999, 2008a): Turions of Aldrovanda vesiculosa, Hydrocharis morsus-ranae, and Spirodela polyrhiza have developed an active mechanism of sinking and rising. It has been suggested that sinking and rising of Aldrovanda turions is caused by variable gas volume in the gas spaces of turion leaves (Adamec 1999, 2003a). On the contrary, Utricularia turions are less dense than water and are dragged by the decaying mother shoots to the bottom. By early spring, the turions separate and float to the surface (Adamec 1999).

As in typical storage organs, the dark respiration rate of turions of 6 aquatic species was rather low compared to dark respiration rates of shoots (leaves) of aquatic plants of the same or other species at a standard temperature (Adamec 2008a) - around 30-75\% lower on a fresh weight (FW) basis and 80-85\% lower per unit DW. Some subtropical or temperate Utricularia species and $A$. vesiculosa populations produce nondormant, quiescent shoot apices, denoted henceforth as "winter apices" (Adamec 2003b, 2008a). However, contrary to true dormant turions, respiration rates in non-dormant winter apices of these two genera were comparable with those in growing aquatic plant shoots (Adamec 2008a). Chapin et al. (1990) defined storage in plants as "resources that build up in the plant and can be mobilized in the future to support biosynthesis for growth or other plant functions". Although all turions function as storage organs on the basis of high non-structural carbohydrate content (Winston \& Gorham 1979, Ley et al. 1997, Adamec 2003a), due to a shortage of data it is not clear whether, and to what degree, they also function as storage for mineral nutrients. Tissue nutrient content of $\mathrm{N}, \mathrm{P}$, and $\mathrm{Mg}$ in $A$. vesiculosa (Adamec 2000) and U. macrorhiza turions (Knight 1988) was comparable with that in shoot apices of the growing plants, but was markedly lower in turions for $\mathrm{K}$ and $\mathrm{Ca}$.

In this paper, tissue nutrient $(\mathrm{N}, \mathrm{P}, \mathrm{K}, \mathrm{Ca}, \mathrm{Mg})$ content was analysed in turions of 5 rooting, non-carnivorous plant species of the genera Caldesia, Hydrocharis, and Potamogeton and in 7 rootless carnivorous plant species of the genera Aldrovanda and Utricularia. The values were then compared with concentrations of these nutrients in the ambient waters in which these species grew. Thus, the aim was to estimate whether turion nutrient content is correlated with nutrient concentrations in the ambient water (sensu Adamec 2008b). Turion nutrient content estimated was compared with the literature data for foliar nutrient content in aquatic plants to decide whether turions represent storage organs also for mineral nutrients. Attention was focused on the comparison of turion nutrient content in two distinct functional plant groups according to mineral nutrition, carnivorous and non-carnivorous plants, which also correspond with the rootless and rooting plants, respectively.

\section{Material and methods}

\section{Plant material and collection sites}

Ripe turions of 12 temperate aquatic plant species were collected either from field sites in the Třeboň Basin Biosphere Reserve and Protected Landscape Area, S Bohemia, Czech Republic (approx. $49^{\circ} \mathrm{N}, 14^{\circ} 45^{\circ} \mathrm{E}$ ) or from artificial cultures in $1-2.5 \mathrm{~m}^{2}$ outdoor plastic containers at the Institute of Botany at Třeboň (see Table 1) during the 2008 autumn from 25 September to 10 November. They were 5 non-carnivorous, rooting species: Caldesia parnassifolia L. (Alismataceae), Hydrocharis morsus-ranae L. (Hydrocharitaceae), Potamogeton acutifolius Link (Potamogetonaceae), P. crispus L., P. obtusifolius Mert. et Koch, and 7 carnivorous rootless species: Utricularia australis R. Br. (Lentibulariaceae), U. vulgaris L., U. minor L., U. bremii Heer, U. stygia Thor (syn. U. ochroleuca Hartm. s.l.), U. intermedia Hayne, and Aldrovanda vesiculosa L. (Droseraceae). Five to 20 turions of each species of a standard size were collected only from one site or culture except for the turions of $U$. australis which were collected from 5 sites differing markedly from each other in trophic status (Table 1, Adamec 2008b). Moreover, in this species, turions of standard length $(6-10 \mathrm{~mm})$ as well as small ones $(2-4 \mathrm{~mm})$ were collected from two field sites to verify whether turion size affects their mineral nutrient content in comparison with that of non-dormant winter apices. Winter apices of a subtropical population of A. vesiculosa from SE Australia (see Adamec 2008a) growing outdoors in cold water were collected for the comparison of tissue nutrient content with that in true, dormant turions within the same species.

\section{Analytical procedures}

Turions of all species used for this study were initiated in September. To obtain some information on water chemistry at the time of turion initiation, water chemistry factors were followed twice at each site or culture within 2-18 September 2008. pH and electrical conductivity were measured directly in the plant zone. Water samples collected from each site were filtered $(5 \mu \mathrm{m})$ and analysed for total alkalinity (TA) and macronutrients $\left(\mathrm{NH}_{4}{ }^{+}-\mathrm{N}, \mathrm{PO}_{4}-\mathrm{P}, \mathrm{K}, \mathrm{Ca}, \mathrm{Mg}\right)$. For further details of analytical methods see Adamec \& Lev (1999). Free $\mathrm{CO}_{2}$ concentration was calculated from TA and $\mathrm{pH}$ according to Helder (1988). 
Table 1. Water chemistry at field microsites or in collection containers from which aquatic plant turions were collected for tissue nutrient analyses. Water samples were sampled two times between 2-18 Sep. 2008. Mean values are shown. G, electrical conductivity; TA, total alkalinity.

\begin{tabular}{|c|c|c|c|c|c|c|c|c|c|c|}
\hline \multirow[t]{2}{*}{ Species } & \multirow[t]{2}{*}{ Site } & \multirow{2}{*}{$\begin{array}{c}\mathrm{G} \\
\mu \mathrm{S} / \mathrm{cm}\end{array}$} & \multirow[t]{2}{*}{$\mathrm{pH}$} & \multirow{2}{*}{$\begin{array}{c}\mathrm{TA} \\
\mathrm{meq} / 1\end{array}$} & \multirow{2}{*}{$\begin{array}{c}{\left[\mathrm{CO}_{2}\right]} \\
\mathrm{mM}\end{array}$} & $\mathrm{NH}_{4}-\mathrm{N}$ & $\mathrm{PO}_{4}-\mathrm{P}$ & $\mathrm{K}^{+}$ & $\mathrm{Ca}^{2+}$ & $\mathrm{Mg}^{2+}$ \\
\hline & & & & & & \multicolumn{2}{|c|}{$\mu \mathrm{g} / 1$} & \multicolumn{3}{|c|}{$\mathrm{mg} / \mathrm{l}$} \\
\hline Cald. parnass. & Collection & 176 & 6.38 & 0.55 & 0.55 & 0.00 & 28.6 & 3.55 & 13.7 & 5.62 \\
\hline $\begin{array}{l}\text { Hydr. m.-ran., } \\
\text { Pot. acutifol., } \\
\text { Utr. australis }\end{array}$ & $\begin{array}{c}\text { Branná } \\
\text { sand-pit } \\
\text { - “- }\end{array}$ & 81 & 6.55 & 0.24 & 0.20 & 5.6 & 2.36 & 1.65 & 5.87 & 3.25 \\
\hline $\begin{array}{l}\text { Pot. crispus, } \\
\text { Pot. obtusifol. }\end{array}$ & $\begin{array}{c}\text { Collection } \\
-" \text { - }\end{array}$ & 106 & 9.00 & 0.46 & 0.001 & 0.00 & 1.64 & 1.58 & 8.50 & 3.62 \\
\hline Utr. australis & Ptačí blato 1 & 251 & 6.95 & 1.66 & 0.44 & 36.0 & 14.7 & 3.68 & 29.3 & 9.21 \\
\hline Utr. australis & Ptačí blato 2 & 308 & 6.97 & 2.06 & 0.54 & 194 & 16.0 & 4.26 & 35.5 & 8.89 \\
\hline Utr. australis & Ruda fishpond & 57 & 5.70 & 0.15 & 0.84 & 0.00 & 16.1 & 1.89 & 5.47 & 3.17 \\
\hline Utr. australis & Cep sind-pit & 84 & 4.76 & -0.03 & 0.030 & 4.1 & 0.55 & 4.38 & 5.42 & 2.74 \\
\hline $\begin{array}{l}\text { Utr. vulgaris, } \\
\text { Utr. stygia }\end{array}$ & $\begin{array}{c}\text { Collection } \\
-“-\end{array}$ & 197 & 7.21 & 0.81 & 0.13 & 4.3 & 0.14 & 2.76 & 19.4 & 3.50 \\
\hline Utr. minor & Ruda peat bog & 48 & 5.09 & 0.044 & 0.82 & 20.1 & 18.3 & 1.43 & 3.14 & 1.96 \\
\hline Utr. bremii & Collection & 220 & 7.15 & 0.54 & 0.11 & 7.9 & 9.24 & 8.32 & 16.1 & 4.81 \\
\hline $\begin{array}{l}\text { Utr. intermed., } \\
\text { Ald. vesiculosa }\end{array}$ & $\begin{array}{l}\text { Výtopa } \\
\text { fishpond }\end{array}$ & 169 & 6.56 & 1.10 & 0.72 & 0.00 & 14.3 & 5.73 & 19.1 & 4.36 \\
\hline
\end{tabular}

The collected turions were cleaned free of detritus, washed thoroughly with tap water, rinsed shortly with distilled water, blotted dry with a soft paper tissue, weighed for FW, dried at $80^{\circ} \mathrm{C}$, and weighed for DW. The dried turions (1-3) were crushed by a pair of forceps. The homogenised dry material was digested and mineralised using concentrated acids, diluted and analysed for N, P, K, Ca, and Mg content. For further sample preparation and analysis details see Adamec (2002).

\section{Statistical procedures}

Mean of two values of water chemistry parameters are shown. $\mathrm{pH}$ values were narrow-ranging, so they were not transformed. Five parallel analyses of turion nutrient content on different turions were conducted for each plant species or $U$. australis site or turion-size category. Means $\pm 1 \mathrm{SE}$ are shown where possible. Linear regression models were used to determine statistically significant relationships between turion nutrient content and water chemistry parameters (Adamec 2008b). Since small $U$. australis turions did not differ markedly in their nutrient content from the standard sizes, they were also included in these regression analyses $(n=18)$. Two-way ANOVA was used to look for significant differences in nutrient content between large and small $U$. australis turions (site and turion size as factors). Oneway ANOVA (Tukey HSD test for multiple comparisons) was used to reveal significant differences in turion nutrient content between $5 \mathrm{U}$. australis populations from different sites. Twoway ANOVA was used to look for significant differences in turion nutrient content between two functional plant groups carnivorous (rootless) and non-carnivorous (rooting) species. In this analysis, the type of functional plant group was selected as a factor with fixed effect, while species, nested within functional group, were chosen as a factor with random effect. For this analysis, small $U$. australis turions were excluded. Significant differences between dormant turions and non-dormant winter apices in A. vesiculosa were tested by a two-tailed t-test.

\section{Results}

The selected sites, from which turions were collected, differed greatly in all parameters of water chemistry (Table 1). Waters were very soft and acidic at several sites (esp. sand-pits), while moderately hard and neutral with high $\mathrm{CO}_{2}$ concentration at others (mainly dystrophic bays of fishponds). According to concentrations of $\mathrm{NH}_{4}{ }^{+}-\mathrm{N}$ and $\mathrm{PO}_{4}-\mathrm{P}$, waters may be considered strongly oligotrophic (one collection container, sandpits) to eutrophic (some fishponds). The proportion of DW to FW of turions of all 12 species ranged from $18.3-37.7 \%$ but the greatest range occurred within 5 U. australis populations (Table 2). Out of all species, the lowest DW proportion by far was found in U. australis turions from a very oligotrophic sand-pit with a low $\mathrm{CO}_{2}$ availability. Mean turion $\mathrm{N}$ content was $1.87 \pm 0.14 \% \mathrm{DW}$ over all species analysed and was not significantly different $(\mathrm{F}=2.29 ; \mathrm{P}=0.16)$ between carnivorous and non-carnivorous species $(2.01 \pm 0.05$ vs. $1.56 \pm 0.17 \%$ DW; Table 2). Mean turion P content $0.257 \%$ DW was not significantly different in both plant groups $(0.261 \pm 0.012$ vs. $0.247 \pm 0.024 \% \mathrm{DW})$, either. Out of all nutrients, only turion K content differed significantly between carnivorous and non-carnivorous species $(0.48 \pm 0.03$ vs. $1.04 \pm 0.10 \% \mathrm{DW})$, while neither $\mathrm{Ca}(0.121 \pm 0.003$ vs. $0.208 \pm 0.025 \%$ DW), $\mathrm{Mg}(0.179 \pm 0.005$ vs. $0.208 \pm 0.019 \%$ DW $)$, $\mathrm{N}: \mathrm{P}$ ratio $(8.39 \pm 2.63$ vs. $6.67 \pm 0.56)$, nor $\mathrm{K}:$ Ca ratio $(4.04 \pm 0.20$ vs. $8.18 \pm 1.61)$ did so. 
Table 2. Tissue nutrient content in ripe dormant turions of 12 species of aquatic plants collected either from field sites or the outdoor collection of the Institute of Botany at Třeboň, Czech Rep. For comparison, the values for non-dormant winter apices of Aldrovanda vesiculosa from SE Australia are shown at the bottom. Means \pm 1 .SE are shown for 5 parallel samples. The proportion of DW to FW is also shown. For Utricularia australis populations, different letters denote significant difference at $\mathrm{P}<0.05$ (1-way ANOVA). The statistically significant difference between both populations of A. vesiculosa $(\mathrm{P}<0.01)$ is indicated by asterisk (twotailed t-test). Statistical significance between carnivorous and non-carnirovous species (2-way ANOVA): **, $\mathrm{P}<0.01 ; *, \mathrm{P}<0.05$; ns, $\mathrm{P}>0.05$.

\begin{tabular}{|c|c|c|c|c|c|c|c|c|c|}
\hline \multirow[t]{2}{*}{ Species } & \multirow[t]{2}{*}{ Site } & \multirow{2}{*}{$\begin{array}{c}\text { DW } \\
(\% \mathrm{FW})\end{array}$} & $\mathrm{N}$ & $\mathrm{P}$ & $\mathrm{K}$ & $\mathrm{Ca}$ & $\mathrm{Mg}$ & \multirow[t]{2}{*}{$\mathrm{N}: \mathrm{P}$} & \multirow[t]{2}{*}{$\mathrm{K}: \mathrm{Ca}$} \\
\hline & & & & & $(\% \mathrm{DW})$ & & & & \\
\hline Caldesia parnassifolia & Collection & 37.1 & $\begin{array}{r}2.03 \\
\pm 0.18\end{array}$ & $\begin{array}{r}0.387 \\
\pm 0.020\end{array}$ & $\begin{array}{r}0.852 \\
\pm 0.106\end{array}$ & $\begin{array}{r}0.049 \\
\pm 0.014\end{array}$ & $\begin{array}{r}0.164 \\
\pm 0.014\end{array}$ & 5.24 & 17.3 \\
\hline Hydrocharis morsus-ranae & Branná sand-pit & 31.4 & $\begin{array}{r}2.75 \\
\pm 0.23\end{array}$ & $\begin{array}{r}0.291 \\
\pm 0.048\end{array}$ & $\begin{array}{r}1.69 \\
\pm 0.11\end{array}$ & $\begin{array}{r}0.193 \\
\pm 0.023\end{array}$ & $\begin{array}{r}0.335 \\
\pm 0.037\end{array}$ & 9.44 & 8.75 \\
\hline Potamogeton acutifolius & Branná sand-pit & 33.8 & $\begin{array}{r}1.26 \\
\pm 0.12\end{array}$ & $\begin{array}{r}0.158 \\
\pm 0.025\end{array}$ & $\begin{array}{r}0.893 \\
\pm 0.050\end{array}$ & $\begin{array}{r}0.221 \\
\pm 0.011\end{array}$ & $\begin{array}{r}0.268 \\
\pm 0.031\end{array}$ & 7.94 & 4.04 \\
\hline Potamogeton crispus & Collection & 32.3 & $\begin{array}{r}0.561 \\
\pm 0.121\end{array}$ & $\begin{array}{r}0.205 \\
\pm 0.063\end{array}$ & $\begin{array}{r}1.04 \\
\pm 0.33\end{array}$ & $\begin{array}{r}0.364 \\
\pm 0.065\end{array}$ & $\begin{array}{r}0.108 \\
\pm 0.008\end{array}$ & 2.73 & 2.85 \\
\hline Potamogeton obtusifolius & Collection & 35.2 & $\begin{array}{r}1.19 \\
\pm 0.08\end{array}$ & $\begin{array}{r}0.193 \\
\pm 0.027\end{array}$ & $\begin{array}{r}0.705 \\
\pm 0.023\end{array}$ & $\begin{array}{r}0.213 \\
\pm 0.016\end{array}$ & $\begin{array}{r}0.167 \\
\pm 0.003\end{array}$ & 6.16 & 3.31 \\
\hline Utricularia australis & Ptačí blato $1^{\text {st }}$ lagoon & 35.4 & $\begin{aligned} & 1.80^{\mathrm{a}} \\
\pm & 0.04\end{aligned}$ & $\begin{aligned} & 0.154^{\mathrm{ac}} \\
\pm & 0.006\end{aligned}$ & $\begin{array}{r}0.271^{\mathrm{a}} \\
\pm 0.005\end{array}$ & $\begin{array}{r}0.089^{\mathrm{a}} \\
\pm 0.013\end{array}$ & $\begin{aligned} & 0.161^{\mathrm{a}} \\
\pm & 0.006\end{aligned}$ & 11.7 & 3.06 \\
\hline Utricularia australis & Ptačí blato $2^{\text {nd }}$ lagoon & 37.7 & $\begin{array}{r}2.08^{\mathrm{a}} \\
\pm 0.06\end{array}$ & $\begin{array}{r}0.150^{c} \\
\pm 0.006\end{array}$ & $\begin{array}{r}0.269^{\mathrm{a}} \\
\pm 0.008\end{array}$ & $\begin{aligned} & 0.112^{\mathrm{ac}} \\
\pm & 0.006\end{aligned}$ & $\begin{array}{r}0.134^{\mathrm{a}} \\
\pm 0.009\end{array}$ & 13.9 & 2.40 \\
\hline Utricularia australis & Branná sand-pit & 27.0 & $\begin{aligned} & 2.07^{\mathrm{a}} \\
\pm & 0.10\end{aligned}$ & $\begin{aligned} & 0.242^{\text {be }} \\
\pm & 0.012\end{aligned}$ & $\begin{aligned} & 0.381^{\mathrm{bd}} \\
\pm & 0.011\end{aligned}$ & $\begin{aligned} & 0.120^{\mathrm{bcd}} \\
\pm & 0.004\end{aligned}$ & $\begin{aligned} & 0.217^{\mathrm{bc}} \\
\pm & 0.005\end{aligned}$ & 8.53 & 3.16 \\
\hline Utricularia australis & Ruda fishpond & 29.0 & $\begin{array}{r}1.78^{\mathrm{a}} \\
\pm 0.17\end{array}$ & $\begin{aligned} & 0.224^{\mathrm{ae}} \\
\pm & 0.009\end{aligned}$ & $\begin{aligned} & 0.356^{\mathrm{ad}} \\
\pm & 0.016\end{aligned}$ & $\begin{aligned} & 0.122^{\text {bcd }} \\
\pm & 0.006\end{aligned}$ & $\begin{aligned} & 0.195^{\mathrm{b}} \\
\pm & 0.005\end{aligned}$ & 7.96 & 2.91 \\
\hline Utricularia australis & Cep sand-pit & 18.3 & $\begin{array}{r}2.02^{\mathrm{a}} \\
\pm 0.14\end{array}$ & $\begin{array}{r}0.375^{\mathrm{d}} \\
\pm 0.035\end{array}$ & $\begin{array}{r}0.839^{c} \\
\pm 0.050\end{array}$ & $\begin{aligned} & 0.117^{\text {ad }} \\
\pm & 0.002\end{aligned}$ & $\begin{array}{r}0.226^{\mathrm{c}} \\
\pm 0.009\end{array}$ & 5.38 & 7.15 \\
\hline Utricularia vulgaris & Collection & 21.1 & $\begin{array}{r}2.07 \\
\pm 0.09\end{array}$ & $\begin{array}{r}0.252 \\
\pm 0.008\end{array}$ & $\begin{array}{r}0.674 \\
\pm 0.081\end{array}$ & $\begin{array}{r}0.169 \\
\pm 0.008\end{array}$ & $\begin{array}{r}0.244 \\
\pm 0.007\end{array}$ & 8.21 & 4.00 \\
\hline Utricularia minor & Ruda peat bog & 29.5 & $\begin{array}{r}2.80 \\
\pm 0.13\end{array}$ & $\begin{array}{r}0.405 \\
\pm 0.027\end{array}$ & $\begin{array}{r}0.585 \\
\pm 0.028\end{array}$ & $\begin{array}{r}0.107 \\
\pm 0.003\end{array}$ & $\begin{array}{r}0.154 \\
\pm 0.006\end{array}$ & 6.91 & 5.48 \\
\hline Utricularia bremii & Collection & 31.6 & $\begin{array}{r}1.57 \\
\pm 0.04\end{array}$ & $\begin{array}{r}0.223 \\
\pm 0.018\end{array}$ & $\begin{array}{r}0.398 \\
\pm 0.014\end{array}$ & $\begin{array}{r}0.147 \\
\pm 0.003\end{array}$ & $\begin{array}{r}0.156 \\
\pm 0.008\end{array}$ & 7.05 & 2.70 \\
\hline Utricularia stygia & Collection & 33.7 & $\begin{array}{r}1.96 \\
\pm 0.14\end{array}$ & $\begin{array}{r}0.298 \\
\pm 0.019\end{array}$ & $\begin{array}{r}0.498 \\
\pm 0.041\end{array}$ & $\begin{array}{r}0.120 \\
\pm 0.005\end{array}$ & $\begin{array}{r}0.178 \\
\pm 0.006\end{array}$ & 6.57 & 4.13 \\
\hline Utricularia intermedia & Výtopa fishpond & 27.0 & $\begin{array}{r}2.18 \\
\pm 0.17\end{array}$ & $\begin{array}{r}0.314 \\
\pm 0.029\end{array}$ & $\begin{array}{r}0.435 \\
\pm 0.027\end{array}$ & $\begin{array}{r}0.116 \\
\pm 0.009\end{array}$ & $\begin{array}{r}0.166 \\
\pm 0.009\end{array}$ & 6.93 & 3.76 \\
\hline Aldrovanda vesiculosa & Výtopa fishpond & 25.2 & $\begin{array}{r}1.84 \\
\pm 0.05\end{array}$ & $\begin{array}{r}0.232^{*} \\
\pm 0.023\end{array}$ & $\begin{array}{r}0.574^{*} \\
\pm 0.019\end{array}$ & $\begin{array}{r}0.110 \\
\pm 0.003\end{array}$ & $\begin{array}{r}0.135^{*} \\
\pm 0.004\end{array}$ & 7.91 & 5.23 \\
\hline $\begin{array}{l}\text { Mean } \pm S E \\
(n=16)\end{array}$ & - & $\begin{array}{l}30.3 \\
\pm 1.4\end{array}$ & $\begin{array}{r}1.87 \\
\pm 0.14\end{array}$ & $\begin{array}{r}0.257 \\
\pm 0.020\end{array}$ & $\begin{array}{r}0.654 \\
\pm 0.091\end{array}$ & $\begin{array}{r}0.148 \\
\pm 0.018\end{array}$ & $\begin{array}{r}0.188 \\
\pm 0.014\end{array}$ & $\begin{array}{r}7.66 \\
\pm 0.64\end{array}$ & $\begin{array}{r}5.02 \\
\pm 0.93\end{array}$ \\
\hline Stat. significance & - & - & ns & $\mathrm{ns}$ & $* *$ & ns & ns & ns & ns \\
\hline $\begin{array}{l}\text { Austr. Aldrovanda vesiculosa } \\
\text { - apices }\end{array}$ & Collection & 20.2 & $\begin{array}{r}2.03 \\
\pm 0.14\end{array}$ & $\begin{array}{r}0.409 \\
\pm 0.013\end{array}$ & $\begin{array}{r}0.994 \\
\pm 0.056\end{array}$ & $\begin{array}{r}0.136 \\
\pm 0.017\end{array}$ & $\begin{array}{r}0.232 \\
\pm 0.006\end{array}$ & 4.96 & 7.29 \\
\hline
\end{tabular}

Within the 5 sites of $U$. australis, significant differences in turion nutrient content were found for all nutrients except for $\mathrm{N}$ (Table 2). The highest values of turion $\mathrm{P}, \mathrm{K}$, and $\mathrm{Mg}$ content were found in the oli- gotrophic Cep sand-pit and this population usually differed significantly from the others in the three nutrients. Large and small $U$. australis turions collected from two sites differed significantly $(\mathrm{P}<0.05,2$-way 
ANOVA, data not shown), but not markedly, only in turion $\mathrm{Mg}$ content and $\mathrm{N}: \mathrm{P}$ ratio from each other, while no significant difference in any parameter was found for site $\times$ turion size interaction. For all plant species and sites $(\mathrm{n}=18)$, no significant $(\mathrm{P}<0.05)$ linear regression model was found between nutrient concentration in the ambient water and turion nutrient content (data not shown). Thus, turion nutrient content did not depend on nutrient concentrations in the ambient water at the time of turion initiation. Of all meaningful linear regressions between turion nutrient contents, only two were found significant (data not shown): $\mathrm{P}=0.095+0.086 \mathrm{~N}\left(\mathrm{r}^{2}=0.35, \mathrm{P}=0.018\right)$ and $\mathrm{Mg}=0.126+0.094 \mathrm{~K}\left(\mathrm{r}^{2}=0.35, \mathrm{P}=0.016\right)$. Taking into account Bonferroni correction to minimize interrelated factors, both regressions were significant (critical level of $\mathrm{P}=0.025$ ). Turion $\mathrm{P}, \mathrm{K}$, and $\mathrm{Mg}$ content in A. vesiculosa was significantly and markedly lower than that in winter apices of the subtropical population of the same species (Table 2).

\section{Discussion}

Although water chemistry at the sites was followed only twice during the period of turion initiation and ripening, the data obtained provide an insight into the nutritional status of the sites. However, due to the fact that $\mathrm{N}$ and $\mathrm{P}$ are predominantly taken up by roots of aquatic plants from sediments (Barko et al. 1991), the data on water chemistry for the sediment-rooted species are rather incomplete. The same objection applies to carnivorous plants, the shoot $\mathrm{N}$ content of which depends markedly on prey capture (Adamec 2008b).

Considering the ecophysiological consequences of tissue mineral nutrient content or accepting this parameter as a general ecological marker of plant mineral nutrition, three important properties of this parameter should be mentioned. They make the ecophysiological interpretation of tissue nutrient content more difficult but, simultaneously, there is evidently no better parameter to be estimated in this context. First, in all plants, tissue nutrient content is a rather variable parameter and depends on many factors some of which are hardly predictable (e.g., time of the season; Gerloff \& Krombholz 1966, Dykyjová 1979, Madsen 1991, Ågren 2008). Second, as tissue nutrient content is "diluted" with organic substances arising from photosynthesis, the values of tissue nutrient content in aquatic plants depend greatly on plant relative growth rate and/or $\mathrm{CO}_{2}$ availability (Titus \& Andorfer 1996, Adamec 2000, 2008b, Ågren 2008). Third, a "luxury" (or excess) nutrient uptake occurs commonly in plants making the organ storage functions less distinct (Gerloff \& Krombholz 1966, Ågren 2008).

The main question associated with the present study is whether turions of aquatic plants also represent storage organs for mineral nutrients. Unlike the winter buds of most terrestrial herbs or trees, turions as propagules represent a whole, complete plant as the rest of the plant decays over winter. Thus, all mineral nutrients allocated for the next season's plant growth are transferred only by turions. Overwintering turions alone with a low intensity of metabolism running at a low temperature probably need only a very low level of mineral nutrients to ensure their maintenance function. Germinating and sprouting turions only enlarge internodes and use reserves of organic and mineral nutrients and, presumably, a new uptake of mineral nutrients from the water or sediment cannot occur until new roots or shoots are formed. Thus, the main mineral storage function of turions could be associated with supporting the growth of new roots or shoots in a relatively cold water. A low net photosynthetic rate can occur in germinating green, free-floating turions (Beer 1985, Adamec 2003a), however, the fate of organic and mineral nutrients stored in turions is quite different over winter: while the content of organic nutrients (carbohydrates) gradually decreases through respiration (Winston \& Gorham 1979, Ley et al. 1997, Adamec 1999, 2003a,b, Weber \& Noodén 2005), mineral content per unit DW should stay constant or increase.

When the turion nutrient content shown in Table 2 for 12 plant species is compared with shoot or leaf nutrient content for the same species (data compiled mainly from Dykyjová 1979, partly from Adamec 2000,2008 b) it is evident that mean nutrient content in growing shoots/leaves is moderately $(\mathrm{N}, \mathrm{P})$ or greatly $(\mathrm{K}, \mathrm{Ca}, \mathrm{Mg})$ higher $(\mathrm{N}, 2.74$ /range $1.31-3.80 / \%$ DW, $\mathrm{n}=12 ; \mathrm{P}, 0.36 / 0.05-0.62 / \%, \mathrm{n}=16 ; \mathrm{K}, 2.84$ $/ 1.70-3.96 / \%, \mathrm{n}=17$; Ca, $2.05 / 0.10-9.0 / \%, \mathrm{n}=19$; $\mathrm{Mg}, 0.70 / 0.16-2.20 / \%, \mathrm{n}=17)$ than in turions. This relationship is further supported by finding higher tissue nutrient content in non-dormant winter apices than in dormant turions of A. vesiculosa (Table 2). Thus, though turions of both rooting and rootless species bear mineral nutrients (mainly $\mathrm{N}$ and $\mathrm{P}$ ) necessary for the first, newly forming organs (roots and shoots), their storage function for mineral nutrients as compared to organic nutrients (carbohydrates) is relatively weak. If the critical $\mathrm{N}$ content in submerged aquatic plants is about $1.3 \%$ DW and $0.13 \%$ DW for P (Gerloff \& Krombholz 1966), theoretically, about $30 \%$ of the mean total turion's $\mathrm{N}$ and about $50 \%$ of the total 
$\mathrm{P}$ amount can be used as storage mineral nutrients for newly sprouting organs, without a decrease in growth rate of the sprouting turions. Certain storage functions of turions for $\mathrm{N}$ and $\mathrm{P}$ also follow from a very efficient $\mathrm{N}$ and $\mathrm{P}$ reutilization from senescent $A$. vesiculosa shoots when turions are formed (Adamec 2000).

Despite the limited number of species studied, the only significant difference in turion nutrient content between two distinct functional plant groups, carnivorous (rootless) and non-carnivorous (rooting) plants, was found for $\mathrm{K}$ content (Table 2). As $\mathrm{K}^{+}$is taken up by rooted submerged plants mainly from the ambient water (Barko et al. 1991) and only a minor part of $\mathrm{K}^{+}$is recovered from prey in aquatic carnivorous plants (Adamec 2008b), obviously, this difference does not refer to different types of mineral nutrition of both functional groups and is rather species-specific. Although turion nutrient content did not depend significantly on mineral nutrient concentration in the ambient water (either for all plant species or separately for both functional groups), the great and significant differences in turion nutrient content (except for $\mathrm{N}$ ) between $5 \mathrm{U}$. australis micropopulations indicate that $\mathrm{CO}_{2}$ concentration could have a marked influence on turion nutrient content (Tables 1, 2). The highest values of turion $\mathrm{P}, \mathrm{K}$, and $\mathrm{Mg}$ content together with the lowest proportion of DW to FW found in the oligotrophic Cep sand-pit were associated with a very low $\mathrm{CO}_{2}$ concentration. The same inverse-proportional relationship between shoot $\mathrm{N}$ and $\mathrm{P}$ content and the ambient $\mathrm{CO}_{2}$ concentration has recently been found in the same species (Adamec 2008b).

In conclusion, turions of aquatic plants also represent storage organs for mineral nutrients $(\mathrm{N}, \mathrm{P})$ though their storage function is presumably less distinct than in the case of carbohydrates. In both functional groups, the accumulation of mineral nutrients in turions does not depend greatly on the availability of the same nutrients in the ambient water but rather on other factors (e.g., efficiency of nutrient reutilization, photosynthetic rate, carbohydrate content).

\section{Acknowledgements}

This study was partly supported by the Research Programme of the Academy of Sciences of the Czech Republic (No. AV0Z60050516). Sincere thanks are due to Dr. Jan Bastl, Mrs. Hana Strusková, and Mrs. Andrea Zajíčková for skilful nutrient analyses and to Dr. Jitka Klimešová for valuable comments and recommendations. Special thanks are due to Mr. Adam Cross, Kings Parks, Australia, for language correction. This study was performed under the permit issued by the Agency of the Nature Conservation of the Czech Republic (No. 01443/TR/2008/ AOPK)

\section{References}

Adamec, L., 1999: Turion overwintering of aquatic carnivorous plants. - Carniv. Plant. Newslett. 28: 19-24.

Adamec, L., 2000: Rootless aquatic plant Aldrovanda vesiculo$s a$ : physiological polarity, mineral nutrition, and importance of carnivory. - Biol. Plant. 43: 113-119.

Adamec, L., 2002: Leaf absorption of mineral nutrients in carnivorous plants stimulates root nutrient uptake. - New Phytol. 155: 89-100.

Adamec, L., 2003a: Ecophysiological characterization of dormancy states in turions of the aquatic carnivorous plant $\mathrm{Al}$ drovanda vesiculosa. - Biol. Plant. 47: 395-402.

Adamec, L., 2003b: Ecophysiological comparison of green Polish and red Australian plants of Aldrovanda vesiculosa. Carniflora Aust. 1: 4-17.

Adamec, L., 2008a: Respiration of turions and winter apices in aquatic carnivorous plants. - Biologia 63: 515-520.

Adamec, L., 2008b: Mineral nutrient relations in the aquatic carnivorous plant Utricularia australis and its investment in carnivory. - Fundam. Appl. Limnol., Arch. Hydrobiol. 171: 175-183.

Adamec, L. \& Lev, J., 1999: The introduction of the aquatic carnivorous plant Aldrovanda vesiculosa L. to new potential sites in the Czech Republic: Five years' investigation. - Folia Geobot. 34: 299-305.

Ågren, G. I., 2008: Stoichiometry and nutrition of plant growth in natural communities. - Annu. Rev. Ecol. Evol. Syst. 39: 153-170.

Barko, J. W., Gunnison, D. \& Carpenter, S. R., 1991: Sediment interactions with submersed macrophyte growth and community dynamics. - Aquat. Bot. 41: 41-65.

Bartley, M. R. \& Spence, D. H. N., 1987: Dormancy and propagation in helophytes and hydrophytes. - Arch. Hydrobiol. Beih. Erg. Limnol. 27: 139-155.

Beer, S., 1985: Effects of $\mathrm{CO}_{2}$ and $\mathrm{O}_{2}$ on the photosynthetic $\mathrm{O}_{2}$ evolution of Spirodela polyrhiza turions. - Plant Physiol. 79: 199-201.

Chapin, F. S. III, Schulze, E. D. \& Mooney, H. A., 1990: The ecology and economics of storage in plants. - Ann. Rev. Ecol. Syst. 21: 423-447.

Dykyjová, D., 1979: Selective uptake of mineral ions and their concentration factors in aquatic higher plants. - Folia Geobot. Phytotax. 14: 267-325.

Gerloff, G. C. \& Krombholz, P. H., 1966: Tissue analysis as a measure of nutrient availability for the growth of angiosperm aquatic plants. - Limnol. Oceanogr. 11: 529-537.

Helder, R. J., 1988: A quantitative approach to the inorganic carbon system in aqueous media used in biological research: dilute solutions isolated from the atmosphere. - Plant Cell Environ. 11: 211-230.

Knight, S. E., 1988: The Ecophysiological Significance of Carnivory in Utricularia vulgaris. - Ph.D. thesis, Univ. Wisconsin, Madison, USA.

Kunii, H., 1989: Continuous growth and clump maintenance of Potamogeton crispus L. in Narutoh river, Japan. - Aquat. Bot. 33: 13-26.

Madsen, J. D., 1991: Resource allocation at the individual plant level. - Aquat. Bot. 41: 67-86.

Ley, S., Dölger, K. \& Appenroth, K. J., 1997: Carbohydrate metabolism as a possible physiological modulator of dormancy in turions of Spirodela polyrhiza (L.) Schleiden. - Plant Sci. 129: $1-7$. 
Newton, R. J., Shelton, D. R., Disharoon, S. \& Duffey, J. E., 1978: Turion formation and germination in Spirodela polyrhiza. - Amer. J. Bot. 65: 421-428.

Sculthorpe, C. D., 1967: The Biology of Aquatic Vascular Plants. - Edward Arnold, London.

Titus, J. E. \& Andorfer, J. H., 1996: Effects of $\mathrm{CO}_{2}$ enrichment on mineral accumulation and nitrogen relations in a submersed macrophyte. - Freshwat. Biol. 36: 661-671.

Submitted: 30 April 2009; accepted: 9 March 2010.
Villanueva, V. R., Simola, L. K. \& Mardon, M., 1985: Polyamines in turions and young plants of Hydrocharis morsus-ranae and Utricularia intermedia. - Phytochemistry 24: 171-172.

Weber, J. A. \& Noodén, L. D., 2005: The causes of sinking and floating in turions of Myriophyllum verticillatum. - Aquat. Bot. 83: 219-226.

Winston, R. D. \& Gorham, P. R., 1979: Turions and dormancy states in Utricularia vulgaris. - Can. J. Bot. 57: 2740-2749. 